\title{
INDEX ACCORDING TO SUBJECTS
}

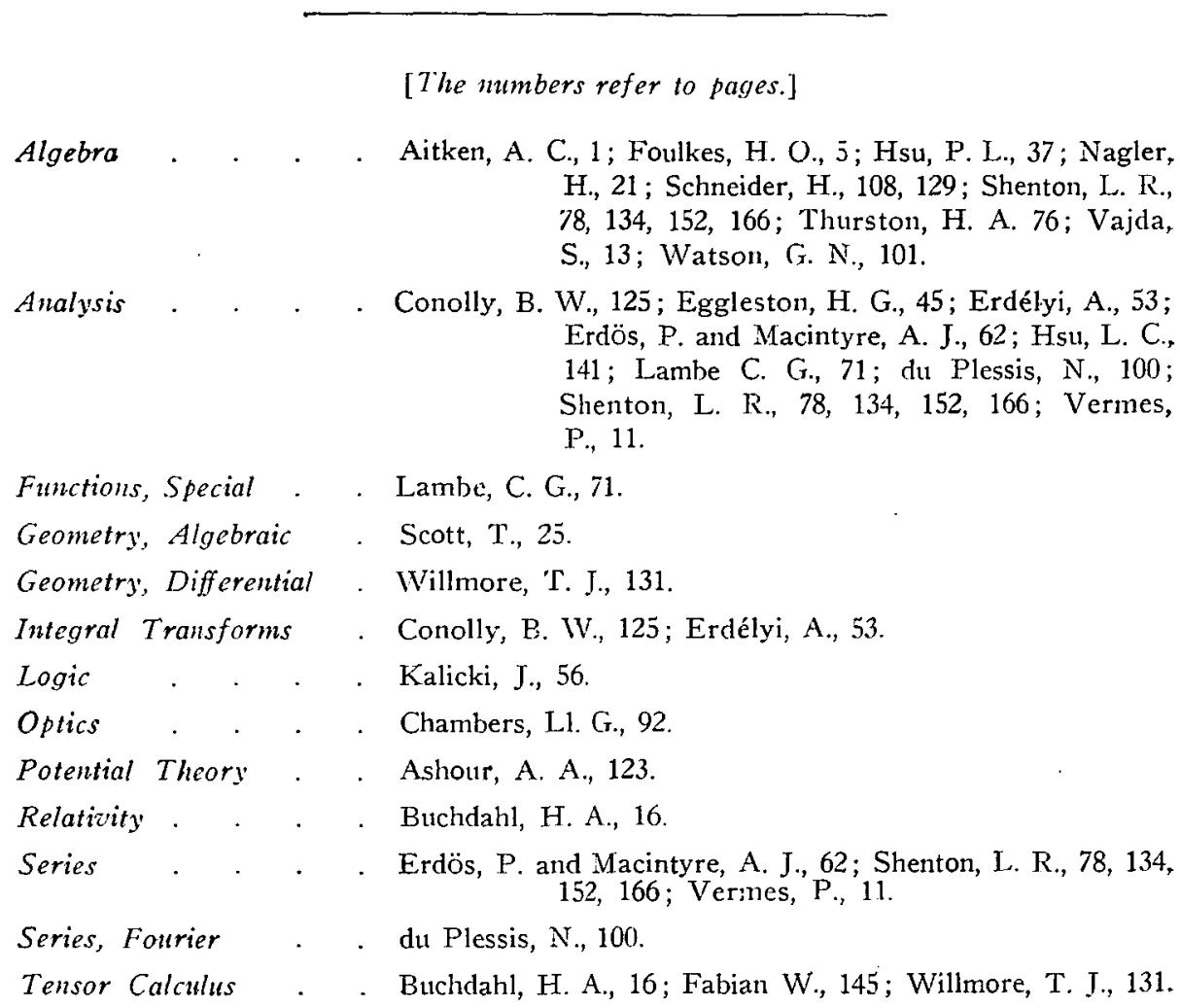

